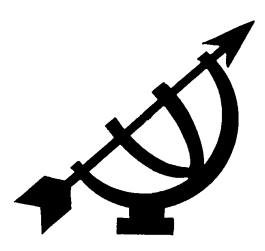

\title{
Onderwys-/opleidingsvoorsiening en ekonomiese aanvraag
}

\author{
J.C. Erasmus, C.C. Wolhuter \\ S.C. Steyn, P.J.Mentz \& J.L. van der Walt
}

Fakulteit Opvoedingswetenskappe

Potchefstroomse Universiteit vir $\mathrm{CHO}$

POTCHEFSTROOM

E-pos: nsoccw@puknet.puk.ac.za

\section{Abstract}

Education/training and economic demand

Education systems and their output appear to be out of step with the demands of the economy in many countries, including South Africa. Massive education investment and expansion seem to have resulted, especially in developing countries, in schooled unemployment rather than economic development, modernisation and full employment. A historicalcomparative overview reveals how economically successful countries such as the United Kingdom, the United States of America, Germany, and (until recently) the new economic giants of South-East Asia and the Far East, succeeded in aligning education and training with the economy. In conclusion the implications of their strategies for South Africa are explored. A combination of the British and Singaporean models is recommended for South Africa. A warning is, however, sounded throughout that economic systems that do not adhere to the principles of human stewardship and responsible management should not be supported by education and training in their present forms. Those involved in education and training should rather call for reform of the systems that they are expected to support.

\section{Inleiding en probleemstelling}

Een van die doelstellings van onderwys- en opleidingstelsels is ekonomiese groei, dit wil sê om die ekonomie te voorsien van 'n geskoolde menslike hulpbronnebasis (vgl. Wolhuter, 1993:53-66). Ten spyte van wêreldwye, massale onderwysinvestering gedurende die afgelope aantal dekades (vgl. Wolhuter, 1993:163-173) neem werkloosheid toe. Terselfdertyd het onderwysuitbreiding (in veral die Derde Wêreld) nie daarin geslaag om ekonomiese ontwikkeling beduidend te bevorder nie. $\mathrm{Na}$ 
beraming was tot $30 \%$ van die wêreldarbeidsmag van 850 miljoen in 1999 werkloos of onderbenut ("underemployed") (Fourie, 1999:360). Geskoolde werkloosheid neem trouens sulke afmetings aan (vgl. World Bank, 1988:70-71; Blaug, 1973; Husén, 1979:9, 18) dat selfs opvoedkundiges begin sinies raak oor die waarde van onderwys (vgl. Fägerlind \& Saha, 1989:4).

Onderwys- en opleidingstelsels en die uitsette daarvan skyn dus uit pas te wees met dit wat die ekonomie verlang of benodig. Daar is byvoorbeeld 'n ooraanbod van werkers wat oor verkeerde en/of verouderde kwalifikasies en vaardighede beskik, sowel as 'n ondervoorsiening van die vaardighede wat 'n snelveranderende, tegnologiese ekonomie vereis (vgl. Blossfeld \& Stockmann, 1999; Douthwaite, 1996:13-29; Murnane \& Levy, 1996:3; Cappelli et al., 1997:165). Navorsing in die vergelykende opvoedkunde het dus klaarblyklik nog nie daarin geslaag om 'n oplossing vir dié probleem te vind nie. Een van die redes hiervoor is die feit, soos wat Fägerlind en Saha (1989:vi-vii) opmerk in hulle gesaghebbende werk oor die verband tussen onderwys en ontwikkeling, dat navorsers in hierdie vakgebied hulle aandag beperk tot konvensionele, formele skoolonderwys, terwyl volwasseneonderwys en -opleiding uit die oog verloor word.

Hierdie soort wanskakeling tussen onderwysuitset en ekonomiese aanvraag veroorsaak in Suid-Afrika nie slegs 'n ekonomiese krisis nie, maar lei ook tot sosio-politieke probleme. Laasgenoemde word onderstreep deur die feit dat daar aan slegs $6 \%$ van die matrikulante wat die 2001matriekeksamen geslaag het, werk verskaf sal kan word (Olivier \& Duvenhage, 2001:2). Die sosio-politieke probleme wat (kan) ontstaan uit die werkloosheid van die oorblywende meer as negentig persent spreek vanself.

In dié artikel word 'n histories-vergelykende oorsig van die verband tussen onderwys-/opleidingsvoorsiening en ekonomie gegee, en word die implikasies vir Suid-Afrika betrek.

\section{Doelstelling en werkwyse}

Die doel van hierdie artikel is om aan die hand van 'n historiesvergelykende oorsig van die ekonomiese ontwikkelingsgang van lande te bepaal hoe lande wat ekonomies suksesvol is (soos Brittanje, die Verenigde State van Amerika, Duitsland en - tot relatief onlangs nog die nuwe ekonomieë van Suidoos-Asië en die Verre Ooste), daarin geslaag het om onderwys/opleiding en die ekonomie in tandem te plaas. Ten slotte word die implikasies van die bevindinge vir Suid-Afrika nagegaan. Die wyse waarop die skakeling tussen die behoeftes van 
ekonomiese stelsels en onderwys- en opleidingsvoorsiening gehanteer word, word ook onderwerp aan prinsipiële beoordeling, gefundeer in 'n reformatoriese denkraamwerk.

\section{Twee (nie-onverwante) ontwikkelingsprosesse waarop ekonomieë tot kompeterende vlakke ontwikkel}

Die eerste proses is die verskuiwing van die ekonomiese swaartepunt vanaf die primêre na die sekondêre en tersiêre sektore. Soos gemeet aan byvoorbeeld die relatiewe bydrae tot Bruto Binnelandse Produk, of die persentasies werkers wat in die onderskeie sektore werksaam is, is die primêre sektor aanvanklik oorheersend, later aan die sekondêre, en dan die tersiêre (Neef, 1999:4). Primêre ekonomiese bedrywe verwys na onttrekkende aktiwiteite (soos landbou, bosbou, mynbou, visvang); sekondêre ekonomiese bedrywe verwys na die vervaardigingsektor (nywerhede), en tersiêre ekonomiese bedrywe verwys na die dienstesektor (soos groot- en kleinhandel, vervoerdienste, professionele dienste, en so meer).

Die tweede proses word toegelig deur Porter (1990:546) se model, wat tussen die volgende vier fases in die ontwikkeling van 'n ekonomie onderskei: faktor-, beleggings-, innovasie- en rykdom-gedrewe fases. Dié model verskaf 'n nuttige verduideliking van hoe ekonomiese ontwikkeling vaardigheidsaanvraag beïnvloed.

\subsection{Fakłorgedrewe ekonomieë}

In 'n faktorgedrewe ekonomie is nywerhede afhanklik van die produkte van die primêre sektor (minerale, landbouprodukte, en so meer), asook van 'n poel van volop beskikbare ongeskoolde of halfgeskoolde arbeid (Porter, 1990:547). Die meeste werkers in 'n faktorgedrewe ekonomie is saamgetrek in produksie, terwyl relatief min werkers nuwe produkte skep (Neef, 1999:5; Porter, 1990:548). Werkers met geen werksvaardighede of -opleiding nie kan die sisteem betree, op die werkplek leer, produktief wees, en sodoende vorder na die volgende sport op die werkleer, selfs tot by toesighoudende en bestuursposte (Cappelli et al., 1997:19). Die vakleerlingstelsel (wat in feodale Europa ontstaan het) is volgens Ashton en Green (1996:149) 'n voorbeeld van hoe opleiding aan werkers verskaf is gedurende die vroeë fase van industrialisasie.

\subsection{Beleggingsgedrewe ekonomieë}

Gedurende hierdie fase van ekonomiese ontwikkeling is beleggingsgeld (kapitaal) nodig vir die bou van moderne, dikwels grootskaalse fabrieke/ fasiliteite, wat toegerus is met die beste beskikbare tegnologie (Porter, 
1990:548). Mededingende voordeel gedurende hierdie fase is gebaseer op die bereidwilligheid en vermoë van 'n land en sy maatskappye/ sakeondernemings om aggressief in die ekonomie te belê. Beleggingsgedrewe ekonomieë word gekenmerk deur produksiebestuur (dit wil sê vervaardiging, elektrisiteit, gas, watervoorsiening en konstruksie), 'n proses waarin die aanwending van die nuutste tegnologie prominent is.

Meganisasie beïnvloed die aanvraag na vaardighede in die arbeidsmark. Geskoolde ambagslui (wat byvoorbeeld voorheen basiese handgereedskap gebruik het om stukke metaal tot die verlangde grootte te saag en te vyl) word in hierdie fase vervang deur masjiene wat beheer word deur ongeskoolde en semigeskoolde operateurs (byvoorbeeld vir die trap van die pedaal van 'n pers) (Prais, 1995:3-4). Ambagslui kan in hierdie fase verder geskool word ten einde te kan voorsien in die aanvraag na masjienmakers en toesighouers.

\subsection{Innovasiegedrewe ekonomieë}

Gedurende die innovasiegedrewe fase neem ondernemings nie slegs tegnologie en metodes van ander lande, bedrywe en stelsels oor en verbeter daarop nie, maar hulle skep dikwels self sodanige tegnologie en metodes (Porter, 1990:554). As gevolg van verbeterde tegnologie vind outomatisasie plaas: die werk van groot getalle ongeskoolde masjienoperateurs word deur outomatiese toestelle oorgeneem (Prais, 1995:4; vgl. Kennedy, 1993:88). Die aanvraag na ongeskoolde en laaggeskoolde werkers neem af en die vraag na geskoolde werkers, wat nodig is om nuwe kapitaaltoerusting te beman en te voorsien, neem toe (Bhorat \& Hodge, 1999:349; Neef, 1999:34; Prais, 1995:4). Uitdiensgestelde ongeskoolde operateurs het op hierdie stadium geen alternatiewe werksgeleenthede nie, aangesien hulle nie gekwalifiseerd is vir die toenemende aanvraag na tegnici, toesighouers, en instandhoudingsingenieurs vir die geoutomatiseerde apparaat nie (Prais, 1995:4). Daarteenoor is ondernemers op soek na werkslui met hoë vaardigheidsvlakke, wat gevorderde tegnologie kan toepas, en daardeur kostes kan besnoei en produksie laat toeneem.

Gedurende die innovasiegedrewe fase van ekonomiese ontwikkeling word die verbruikersaanvraag meer gesofistikeerd, hoofsaaklik as gevolg van stygende persoonlike inkomstevlakke, 'n hoër onderwyspeil, toenemende gemaksug (Porter, 1990:553) en hebsug. Die tersiêre ekonomiese sektor, wat in hierdie behoeftes moet voorsien, raak al meer prominent. Nog 'n ekonomiese verandering is die toenemende voorkoms van kontingentwerkers (kontrak-, deeltydse en tydelike werkers). In hierdie fase kry werkers 'n groter aandeel in die dra van die risiko's van ondernemings, neem hulle meer verantwoordelikheid vir die bestuur van 
hulle eie loopbane en word hulle verhouding met werkgewers in 'n groter mate deur markkragte bepaal (Cappelli et al., 1997:4; Douthwaite, 1996:27).

\subsection{Rykdomgedrewe ekonomieë}

Twee opvallende kenmerke van rykdomgedrewe ekonomieë is eerstens dat ondernemings voortdurend trag om personeel te besnoei ten einde kompeterend te bly, en tweedens die neiging het om ondernemings op groot skaal saam te voeg. Albei hierdie tendense veroorsaak ' $n$ verlangsaming in die groei van die getal werkgeleenthede, wat toenemende werkloosheid tot gevolg het. Hierdie fase word dikwels ook gekenmerk deur korporatiewe groei, gierigheid en hebsug. Die uiteinde hiervan kan wees dat die mens bedreig begin voel deur sy eie handewerk: die high tech-omgewing van die moderne ekonomie neig om die mens oorbodig te maak (Kuiper, 1995:v).

\subsection{Evaluering en perspektief: "gierigheids- en hebsuggedrewe" ekonomieë}

Porter se model is, soos enige model, 'n simulasie en vereenvoudiging van 'n komplekse werklikheid. Terwyl die model duidelik vier hoofdryfkragte op verskillende stadia van ekonomiese ontwikkeling enkapsuleer, verreken dit nie heelwat tendense wat die ekonomie in die hedendaagse samelewing vorm en kenmerk nie, byvoorbeeld die inligtings- en kommunikasierevolusie, asook die opkoms van die informele ekonomiese sektor en ondernemerskap. Die tydruimtelike wisseling van die rol van die staat in die ekonomie word ook uitgesluit. Wanneer die model vervolgens toegepas gaan word om die skakeling van onderwys en ekonomie te ondersoek, sal dié tekortkominge in gedagte gehou word. Veral die rol van die staat sal bygevoeg moet word.

Ter wille van prinsipiële ewewig moet die Porter-model aangevul word met 'n verdere perspektief. Reeds so lank terug as 1939 het die reformatoriese denker Herman Dooyeweerd verwys na die grondmotief van "beheer oor die natuur". Die natuur word deur sowel die wetenskap as die tegnologie beheer, veral in die derde en vierde fases van ekonomiese ontwikkeling wat deur Porter onderskei is. Schuurman (1995: 133-135) stem met hierdie insig van Dooyeweerd saam: die opkoms van die moderne wetenskap het die opkoms van die tegnologie voorafgegaan. Die religieuse grondmotief agter die opkoms van die moderne wetenskap en tegnologie kan beskryf word as 'n "skeppingsmag" kenmerkend van wetenskaplike (teoretiese) denke wat, nadat dit die Godgegewe skeppingsorde afgebreek het, 'n nuwe orde tot stand gebring het wat voldoen aan die eise van die menslike outonomie. Die 
"wetenskapsideaal" van die hedendaagse mens kom neer op 'n strewe om te beheer. Dit is met ander woorde 'n tegnologiese ideaal. Die outonome mens van die moderne tyd gebruik die "natuur" (die skepping) as die arena vir die uitlewing van sy vrye persoonlikheid, die arena waarin hy die skepping beheer en tot wetenskaplik-tegnisistiese onderwerping dwing, en waardeur hy sy gierigheid en inhaligheid kan bevredig. Die religieuse grondmotief van die hedendaagse kultuur, insluitende die hoogs ontwikkelde en mededingende ekonomieë, kan dus soos volg geformuleer word: kreatiewe vryheid van mense (die persoonlikheidsideaal) soos gekonsentreer in wetenskaplik-tegnologiese beheer of mag. In die derde en vierde fases wat Porter onderskei, leef die mens dus inderdaad in 'n gees van instrumentalisme, met ander woorde hy streef na die onderwerping van die kultuur aan die gees van verabsoluteerde tegnologiese mag.

Deur tegnologiese en ekonomiese vooruitgang die hoofdoel van die mens en sy kultuur te maak, verontagsaam die mens as 't ware die perke wat God in sy wysheid aan die mens gestel het. Baie mense reageer daarteen deur middel van opstand en revolusie (Schuurman, 1987:20). Om hierdie rede is daar sedert 1789 gereelde rewolusies in die ontwikkelde lande, in die onlangse tye teen die ontwikkeling van tegnologie rondom kernwapens en -krag, die vernietiging van woude, die jag van walvisse, die besoedeling van die atmosfeer en van die Antarktika, die ekonomiese stelsels en planne van die G8-lande. Groen partye in die ontwikkelde lande spreek hulle weerstand teen die ideaal van vinnige groei en ontwikkeling deur middel van wetenskaplike tegnologie uit. Hierdie "vyfde fase" van ekonomiese ontwikkeling word gekenmerk deur mense

... who believe that revolution should be a basic attitude to life, a way of life rather than a series of one-off protests, violent or otherwise. It is these people who oppose the evolutionists and their attempts to set up all-encompassing control systems ... (Schuurman, 1987:20).

Hierdie "vyfde fase" van ontwikkeling het in die afgelope dekade duidelik beslag gekry in die Verre Ooste en Suidoos-Asië. Hierdie ekonomieë, wat net soos die G8-ekonomieë (vgl. McCready, 2001:23) gekenmerk is deur 'n strewe om die mees mededingende, dinamiese en kennisgedrewe ekonomiese stelsels in die wêreld te wees, het in die afgelope dekade onverwags ernstige terugslae gely. Die bars van die economic bubbles van Suidoos-Asië en die Verre Ooste sowel as die dot.com bomb van informasietegnologie-bedrywe toon hoedat gierigheid en inhaligheid uiteindelik op hulself boemerang. As gevolg van hierdie verskynsels het rykdom in die wêreld (soos gemeet aan die Dow Jones-, die FTSE-, die CAC40-, die DAX-, die Hang Seng- en die Nikkei-indekse) 
met sowat een derde gedaal sedert die begin van 2001. In Indonesië is die hoogs gevorderde ekonomie van die land besig om homself te vernietig deur middel van hoë belastings, onder meer vir luukse goedere. Dit veroorsaak die onttrekking van vervaardigers, wat op sy beurt sorg vir groot werkloosheid (Go, 2001:4).

Die reaksie van jongmense in Japan is kenmerkend van hoe die revolusionêre "vyfde fase" tot uitdrukking kom:

For the past 10 years, they have lived in the shadow of the country's deepest post-war economic resession, a decade that has left many of them disillusioned and apathetic. If they stick to their promises and dreams, tomorrow's Japan could look very different from the rigidlycorporised country the world has come to know. Young people are showing little loyalty to a system that once delivered unparalleled prosperity to Japan but is paralysed now by inertia and crisis (Fuller, 2001:21).

Middleton en Walsh (1995:23-26) meen tereg dat hierdie fase in kultuurontwikkeling, insluitende ekonomiese ontwikkeling, gekenmerk word deur 'n "profound loss of hope and sense of angst", deur 'n gevoel onder bedreigde mense "as if (they) are in the depths of a cultural winter", en dat hulle beheers word deur 'n "psychology of fear".

\subsection{Samevatting: Die ontwikkelingsgang van ekonomieë, die vaardigheidsaanvraag en die noodsaaklikheid van 'n prinsipiële perspektief}

Soos 'n ekonomie deur die vermelde vyf fases beweeg, mede onder die invloed van samelewingskragte (soos tegnologiese vooruitgang, snelle verandering as gevolg van innovasie, gierigheid en inhaligheid, en die revolusionêre reaksies daarop), word dit al noodsaakliker vir werkers om hulleself met die nodige vaardighede toe te rus. Dit vereis ' $n$ hoër opleidingspeil. As hulle dit nie doen nie, bevind hulle hulle in die geledere van die werkloses, of word hulle deur die ekonomiese omstandighede uitgebuit. Vinnig veranderende tegnologiese en marktoestande in 'n moderne ekonomie lei daarby maklik tot 'n ooraanbod van ongeskoolde werkers, of werkers met uitgediende vaardighede, asook tot uitbuiting, of die besoedeling van die omgewing. Ook werkers wat die nodige vaardighede kortkom om te beweeg na nuwe werkgeleenthede, loop die gevaar om hulle werk te verloor (Murnane \& Levy, 1996:13). 'n Hoërskooleindsertifikaat is byvoorbeeld nie meer in aanvraag by 'n werkgewer in die nuwe ekonomie nie (Cappelli et al., 1997:165).

Die vyfde fase toon daarby ook dat hoogs ontwikkelde ekonomieë die kiem van hulle eie ondergang kan dra. Mense moet opgelei wees om 
hierdie gevaar te verstaan en om verantwoordelik om te gaan met ekonomiese en tegnologiese innovasie en ontwikkeling.

Om al hierdie redes is dit noodsaaklik om ondersoek in te stel na hoe suksesvolle mededingende ekonomieë - Brittanje, VSA, Duitsland, (tot relatief onlangs) Japan en die nuwe ekonomieë van die Stille Oseaanring - daarin geslaag het om onderwys/opleiding en ekonomie in pas te bring. Dié lande het almal daarin geslaag om sedert die Tweede Wêreldoorlog sowel positiewe per capita ekonomiese groeikoerse te handhaaf, as om werkloosheid tot enkelpersentasiesyfers te beperk (International Labour Office, 2000:44-457). Soos aangedui, het sommige van hierdie suksesvolle ekonomieë byna weer ten gronde gegaan weens die feit dat sekere fundamentele perspektiewe nie in aanmerking geneem is nie. Teen hierdie agtergrond is dit belangrik dat die ondersoek na die gepaste koppeling van die onderwys/opleiding met die eise van die ekonomie, op 'n korrekte prinsipiële grondslag gedoen sal word. Vir die doeleindes van hierdie bespreking word die grondslag gevind in die reformatoriese beginsels van rentmeesterskap en verantwoordelike responsiwiteit op God se openbaring. Voordat die ondersoek voortgesit kan word, moet nou eers kortliks aandag geskenk word aan hierdie twee beginsels en hulle implikasies vir die onderhawige tema.

\section{Prinsipiële riglyne}

\subsection{Die mens as rentmeester van God}

Om die verband tussen onderwys/opleiding en die ontwikkeling van die ekonomie in die regte lig te kan benader, is dit noodsaaklik om te besef dat die God van die Bybel volgens reformatoriese standpunt die Skepper en Onderhouer van alle dinge is. Hy is in finale instansie die Eienaar of die Besitter van alles waarmee die mens in die skepping te doen kry en waarmee die mens homself bemoei. Hierdie insig beteken dat die mens nie met die skepping kan omgaan asof dit aan hom behoort nie. Die mens mag dus nie die skepping, insluitende die medemens (in die persoon van die werknemer), tegnologies uitput, uitbuit of die omgewing besoedel nie. Die mens, so leer die Bybel, is in die skepping geplaas om dit te bewoon, te bewaak en te bewerk. Die mens is dus God se rentmeester, verteenwoordiger, agent, ambassadeur of vise-regent (Middleton \& Walsh, 1995:121-123): hy moet die skepping so ontwikkel en bestuur dat dit God en die medemens sal dien. Die kultuurskeppende hand van die mens moet onder meer lei tot die verdere ontplooiing van die skepping tot God se eer en die voordeel van die mensdom. Deur hierdie kultuurskeppende arbeid van die mens moet hy vir homself en vir sy medemens 'n woning in die skepping maak. Kultuurskeppende handelinge moet, in die gees van rentmeesterskap, lei tot steeds ver- 
diepte toewyding van die mens en sy werke aan God en sy eer (Middleton \& Walsh, 1995:119-125).

\subsection{Verantwoordelike respons op Goddelike openbaring}

Hierdie tweede beginsel sluit by die eerste aan. Die mens is geskape asook geroepe as God se rentmeester in die skepping om verantwoordelik te respondeer op God se openbaring.

Die mens staan in 'n verbondsverhouding met God, 'n verbond waarin God die groot Bondgenoot is wat die inisiatief neem waarop ons dan moet reageer. Hoe neem Hy die inisiatief? As ons dit weet, sal dit ons help om te weet hoe ons moet reageer. Hy is die Verbondsgod wat die inisiatief neem. Hy praat. Om komplementêr (paslik) te reageer, moet ons hoor en gehoorsaam. Daarin lê ons wese opgesluit. Só is ons mense soos Hy dit bedoel het. Ons ore sê dus veel meer oor ons wese as ons 'siel' (König, 2001:158-160).

God openbaar Homself in sy Woord, wat verskillende gestaltes aanneem: sy skeppingswoord, sy onderhoudingswoord in die skepping, sy Vleesgeworde Woord Jesus Christus, sy wetwoord in die skepping waardeur Hy orde aan die skepping gee en dit in stand hou (Taljaard, 1995:1- 44). Die mens, as rentmeester van God, leef dus nie in God se skepping asof hy vir homself leef nie. In prinsipe behoort elke mens daarvan bewus te wees dat menslike bestaan en lewe, elke handeling en aktiwiteit, gelowige respons op God se openbaring behoort te wees.

Hierdie twee beginsels is rigtinggewend in die bespreking van die onderhawige tema. In die strewe na die ontwikkeling van die ekonomie, onder meer deur gepaste onderwys- en opleidingsvoorsiening, behoort die mens in prinsipe bewus van sy of haar rentmeesterskap te wees, asook van die feit dat ekonomiese ontwikkeling en die dienooreenkomstige onderwys- en opleidingsvoorsiening moet voldoen aan die eis van verantwoordelike respons op God se openbaring en roeping. Die suksesvolle voldoening aan die strewe na ekonomiese ontwikkeling aan die een kant, en die voorsiening van onderwys en opleiding om dit te verwesenlik aan die ander kant, is afhanklik van die erkenning van hierdie twee beginsels.

Die verband tussen vaardigheids- en ekonomiese ontwikkeling wat hieronder beskryf word, moet dus eventueel teen die agtergrond van hierdie twee beginsels beoordeel word.

\section{Vaardigheidsopleiding in kompeterende ekonomieë}

Soos in 2 hierbo uiteengesit, is die vaardighede van 'n land se werksmag 'n bepaler van sy ekonomiese sukses (vgl. Ashton \& Green, 1996:95; Griffiths \& Jones, 1980:8; Murray, 1999:4; Van Dyk et al., 1997:9). 
Wanneer werkers vaardighede verwerf, word hulle nie net meer produktief nie, maar as 'n reël word ook hulle ook meer vatbaar vir veranderinge by die werkplek (Badenhorst, 2000:29; Booth \& Snower, 1996:1; Wells, 1999:24). Vervolgens word 'n oorsig gegee van hoe die mees kompeterende ekonomieë daarin geslaag het om hulle arbeidsmag met die nodige vaardighede, soos deur die ekonomie vereis, toe te rus.

\subsection{Vaardigheidsvorming in eerstegolf-geïndustrialiseerde lande: Brittanje en die VSA}

Die Industriële Revolusie van die agtiende en negentiende eeue het die ekonomieë van Brittanje en die VSA getransformeer vanaf agrariese na geïndustrialiseerde ekonomieë (Goodey, 1996:181; Theron \& Van Staden, 1989:549). Volgens Ashton en Green (1996:119, 129) was die vroegste nywerhede - yster- en tekstielnywerhede - afhanklik van volop ongeskoolde arbeid. Dit was op daardie stadium genoeg om skole te hê wat werkers kon lewer wat die roetine eie aan massaproduksie kon aanvaar. Gevolglik is nasionale stelsels van primêre skole en primêre skoolplig in Engeland en die VSA in die negentiende eeu ingestel (vgl. Duggan, 1916:393-407; 437-441).

Nuwe wetenskapgebaseerde nywerhede het 'n verhoogde aanvraag na hoëre intellektuele vaardighede in die algemeen, en tegniese en bestuursvaardighede in die besonder geskep. Nasionale sekondêre onderwysstelsels en sekondêre skoolplig is ingestel gedurende die eerste helfte van die twintigste eeu, byvoorbeeld onder die 1944-Onderwyswet in Engeland (vgl. Goodey, 1989:126). Tegniese hoërskole is opgerig. Gedurende die tweede helfte van die twintigste eeu is ook die oorgang vanaf elite- na massa-tersiêre onderwys voltrek. Naas 'n fenomenale groei in die getal universiteite is polytechnics in Brittanje gestig vir tersiêre tegniese onderwys.

Veranderinge in die ekonomieë van Brittanje en die VSA, soos aangetoon in 3 hierbo, het beteken dat die konvensionele onderwys-/ opleidingstelsel nie meer voldoende in die ekonomiese aanvraag kon voorsien nie. Ook kan dit nie volledige indiensneming, met ander woorde werk vir die bevolking, waarborg nie (vgl. Porter, 1990:553; Ashton \& Green, 1996:133; Hoare \& Jolly, 1999). Gevolglik moes nuwe strategieë bedink word om die vaardighede van die werkmag voortdurend (lewenslank) te bly slyp ten einde hulle vir die ekonomie nuttig te laat bly.

In die VSA is werkgewers aangemoedig om self inisiatief te neem om opleiding te verskaf met die instelling van Private Industry Councils (PIC's). Die doel van dié rade en geassosieerde opleidingsinrigtings was om werkgewers in staat te stel om beheer te neem van regerings- 
hulpbronne wat geoormerk is vir opleiding, aangesien dié werkgewers meer gevoelig is vir die behoeftes van die mark (Ashton \& Green, 1996: 180).

Gedurende die afgelope paar jaar is nuwe strategieë in Engeland toegepas. Nasionale opleidingsorganisasies (National Training Organisations - NTO's) is in die lewe geroep wat arbeidsmarkbehoeftes identifiseer (Powell, 1999:43-46). Werkgewers kry die geleentheid om uit te spel watter vaardighede hulle benodig, asook op watter wyse dié vaardighede verwerf kan word. NTO's vir elke beroepsektor is verantwoordelik vir die ontwikkeling van nasionale opleidingsprogramme vir elke beroepsektor, soos ooreengekom.

In 1998 het die Employment Service van die Verenigde Koninkryk die regering se New Deal Programmes vir jeugdiges van 18-24 jaar, asook vir ouer persone wat al langer as twee jaar werkloos is, van stapel gestuur (Lewis, 1999:34). Die Employment Service is deel van die Department of Education and Employment, en bedien 33000 werkers, wat in meer as 1000 sentra regoor die land werksaam is. Die hooffunksie van die Employment Service is om betrekkings te bekom vir werkloses en terselfdertyd werkgewers te help om vakante poste te vul.

Vir jeugdiges (18-24 jaar oud) wat ses maande of langer werkloos is, bied die New Deal vier moontlikhede - wat almal ten minste ses maande duur, en onderwys en opleiding ter verwerwing van kwalifikasies insluit (Lewis, 1999:35). Ingevolge die eerste moontlikheid, die Employment Option, ontvang werkgewers vir ses maande 'n subsidie vir elke werker wat hulle kragtens die skema in diens neem. Sodanige werkgewers moet werkers 'n opleidingsekwivalent van een dag per week ter verwerwing van 'n erkende kwalifikasie gee.

In terme van die tweede opsie, die Education and Training Option, het jeugdiges die geleentheid om vir twaalf maande aan 'n kollege of by 'n opleidingsverskaffer te studeer vir 'n kwalifikasie wat hulle indiensnemingskanse sal verhoog. Vir die duur van die twaalf maande ontvang hulle die ekwivalent van 'n werksoekerstoelaag (Jobseekers Allowance).

Jeugdiges wat besluit op die derde opsie, die Environmental Task Force Option, werk vir ses maande vir 'n werkgewer waar hulle werk ook die omgewing en die gemeenskap ophef. Die opleiding wat hulle ontvang, is ter verwerwing van 'n erkende kwalifikasie. Vir die duur van die ses maande ontvang hulle ook die ekwivalent van 'n werksoekerstoelaag.

Onder die laaste opsie, die Voluntary Sector Option, word deelnemers die geleentheid gegee om vir 'n tydperk van ses maande vir 'n vrywillige organisasie te werk. Soos in die geval van die vorige opsie, deurloop 
hulle opleiding ter verwerwing van 'n erkende kwalifikasie en ontvang hulle die ekwivalent van 'n werksoekerstoelaag.

Werksoekers ouer as 25 jaar wat al langer as twee jaar werkloos is, kan ook voordeel trek uit die New Deal Programme (Lewis, 1999:36). Hulle word die geleentheid gebied om te studeer of om vir 'n tydperk van 'n jaar heropleiding te ondergaan. Hulle ontvang gedurende dié periode 'n werksoekerstoelaag.

\subsection{Vaardigheidsvorming in tweedegolf-geïndustrialiseerde lande: Duitsland en Japan}

Die eerstegolf-geïndustrialiseerde lande (Brittanje en die VSA) het geïndustrialiseer op die basis van die ou (laat feodale) ambagstegnologie, gebaseer op stoomkrag vir massaproduksie. Vir die tweedegolf-geïndustrialiseerde lande, soos Duitsland en Japan, was die tegnologie van die tweede industriële rewolusie (elektrisiteit en ander vorme van energie) reeds beskikbaar op die tydstip (laat-19de eeu) toe hulle begin het om te industrialiseer (Ashton \& Green, 1996:138; vgl. ook Dekker, 1995:66; Porter, 1990:715). Volgens Porter (1990:560-569) het Duitsland reeds voor, en Japan kort na die Tweede Wêreldoorlog die innovasiegedrewe fase van ekonomiese ontwikkeling binnegegaan.

Die tweedegolf-geïndustrialiseerde state het die voordeel gehad dat hulle kon leer uit die ondervinding van die eerste golf, maar aan die ander kant was daar ook die uitdaging om by hulle te bly in 'n al meer globale, kompeterende wêreld (Ashton \& Green, 1996:138). Die begeerte om op te vang, asook hierdie lande se regerings se konseptualisering van industrialisasie as 'n deel van die staat se taak, het 'n deurslaggewende invloed uitgeoefen op die ontwikkeling van die onderwys- en opleidingstelsels, veral ten opsigte van die behoeftes van die ekonomie. Die Duitse en Japannese regerings het staatsbronne dus doelbewus aangewend om die proses van industrialisasie te versnel (Ashton \& Green, 1996:139; Dekker, 1995:66; Pretorius, 1995:336). In albei lande is 'n vennootskap tussen regering, nyweraars en werkers gesmee om die nywerheidsrevolusie aan te vuur (Booth \& Snower, 1996:3). 'n Deel van die agenda was die opleiding van 'n hoogs geskoolde arbeidsmag vir die nuwe nywerhede (Porter, 1990:139). Gevolglik het albei lande 'n kombinasie van die volgende voorsien: algemene skoolonderwys wat deur die staat moontlik gemaak word en werkgebaseerde opleiding wat deur die werkgewer verskaf word.

Duitsland het ' $n$ nasionale stelsel van tegniese onderwys ingestel wat afgestem is op die behoeftes van die industrie, naamlik die tweeledige stelsel van ambagsopleiding (Porter, 1990:369). Dié stelsel is dubbel in 
die sin dat opleiding op twee plekke verskaf word: die beroepskool (Berufschule) en die werkplek. Opleiding word op nasionale en industrievlak gestandaardiseer en gereguleer. Beroepskole, wat deeltyds deur deelnemers aan die stelsel bygewoon word, verskaf die teoretiese basis en kennis wat nodig is vir die industrie, asook basiese onderwys. Opleiding in die werkplek word georganiseer op die basis van 'n kontrak tussen werkgewer en werknemer, en word gekenmerk deur die sistematiese aard daarvan, soos gedefinieer deur die kurrikulum en die teenwoordigheid van die Meister, wat opgelei is in die vaardigheid om vakleerlinge op te lei (Cantor, 1989:105). Dié stelsel dek feitlik alle sektore van die Duitse ekonomie, nie net vervaardiging en landbou nie, maar ook die bank- en versekeringswese, gesondheids- en kleinhandelsdienste (Dekker, 1995:99). Die omvang van die dubbele stelsel is aansienlik, nie slegs wat betref ekonomiese sektore nie, maar ook in terme van die getal jeugdiges wat aan die stelsel deelneem. Ongeveer die helfte van alle jeugdiges wat skoolverlatingsouderdom bereik, maak gebruik van dié stelsel (Edwards, 1997:178).

In Japan is die hulpbronne van die staat eweneens aangewend om nywerhede wat op die wêreldmark wil meeding te help ontwikkel, en is onderwys ook beskou as deel van die projek. Onderwys wat voorsien is deur die staat en wat op 'n akademiese kurrikulum gebaseer is, is uitgebrei. Sodoende is 'n stelsel van hoër onderwys in die lewe geroep om die privaatsektor te voorsien van ingenieurs en wetenskaplike en professionele personeel (Pretorius, 1995:336). Hierdie stappe het gelei tot hoë vlakke van massaprestasie in die basiese vaardighede ten opsigte van wiskunde, wetenskap, tegnologie en tale. Firmas kon hierop voorbou deur middel van opleiding in gevorderde, werkgebaseerde vaardighede in 'n stelsel van lewenslange indiensneming (Ashton \& Green, 1996:139; Stiglitz, 1996: 165).

Werkgewers het vroeëre pogings (in 1880 en 1920) om vakleerlingopleiding in die Japannese skoolstelsel te inkorporeer, teengestaan (Ashton \& Green, 1996:148-150). Hulle het werkplekgebaseerde vakleerlingopleiding en heropleiding vir hulle geskoolde werkers verkies, terwyl die onderwysstelsel die roete vir die hoër statusberoepe geword het. $\mathrm{Na}$ die Tweede Wêreldoorlog is die Ministerie van Arbeid gevorm met die doel om toesig te hou oor die opleidingstandaarde in die industrie. ' $n$ Nasionale stelsel van ambagsertifikate is ingestel ten einde die status van blouboordjiewerkers te verhoog (Ashton \& Green, 1996: 148-150).

Alhoewel Duitsland en Japan daarin geslaag het om hulle ekonomieë met die verlangde menslike kapitaal te voorsien, toon hulle opleidingstelsels ook tekortkominge. Duitsland se stelsel kort byvoorbeeld 'n 
komponent van lewenslange opleiding. Die Japannese stelsel het weer gelei tot 'n tekort aan vaardigheidsontwikkeling vir die dienstesektor (Ashton \& Green, 1996:154, Edwards, 1997:182). Albei bied geen vooruitsigte vir werklose jeugdiges en volwassenes nie.

\subsection{Vaardigheidsvorming in derdegolf-geïndustrialiseerde lande: die nuwe ekonomieë van Suidoos-Asië}

$\mathrm{Na}$ die Tweede Wêreldoorlog het die derdegolfnywerheidslande van die Stille Oseaanring (soos Thailand, Suid-Korea, Singapoer en Taiwan) geïndustrialiseer en moes hulle toetree tot die ekonomiese terrein wat reeds deur Europese, Japannese en Amerikaanse maatskappye beheer was (Ashton \& Green, 1996:155-156). Hierdie nuwe geïndustrialiseerde ekonomieë het die geleentheid gehad om te leer uit die eerste twee golwe van industrialisasie. Japan het vir hulle 'n voorbeeld gebied van hoe 'n laat-ontwikkelde land, deur 'n toegewyde poging en ingestel op geselekteerde produkte, suksesvol kon deurbreek tot die wêreldmark (World Bank, 1993:8). Soos Japan, anders as Duitsland, het hulle nie 'n sterk vaardigheidsopleidingstradisie gehad om op te bou nie (Ashton \& Green, 1996:156). Hulle het egter nie die uitgebreide netwerk van inheemse werkgewers gehad (soos Japan), waarop 'n stelsel van lewenslange vaardigheidsopleiding en -inoefening gebou kon word nie. Gevolglik het hierdie lande die Japannese model oorgeneem, maar 'n veel groter rol aan die staat vir vaardigheidsopleiding toegeken. Die regering kon nie die vaardigheidsopleiding aan die industrieë oorlaat nie, en het daarom ' $n$ enorme belegging in menslike hulpbronontwikkeling gemaak.

Dit het 'n funksie van die staat geword om veranderinge in die ekonomie te monitor en te antisipeer, en die proses van vaardigheidsverwerwing dienooreenkomstig te stuur (Ashton \& Green, 1996:157-158; Stiglitz, 1996:151-153). 'n Effektiewe onderwys- en opleidingsinfrastruktuur is ontwikkel, ten einde

- onderrig te verskaf in basiese vaardighede in wiskunde, taal, wetenskap en tegnologie, soos deur die industrie vereis (Ashton \& Green, 1996:158; Stiglitz, 1996:157; World Bank, 1993:21);

- te verseker dat die tegnologiese vaardighede wat vir die mees gevorderde vorme van produksie benodig word, vanaf ouer nywerheidslande en hulle multinasionale maatskappye oorgedra word en plaaslik geproduseer word (Ashton \& Green, 1996:158; Stiglitz, 1996: 153);

- veranderinge te antisipeer in die vaardighede wat in aanvraag sal wees gedurende verdere fases van aanpassing by die wêreldmarkte; 
- meganismes te verskaf waarvolgens sodanige vaardighede gegenereer kan word (Ashton \& Green, 1996:158; Stiglitz, 1996:154).

Die regering van Singapoer, in die besonder, koördineer veranderinge in onderwys en opleidingsbeleid ten einde die suksesvolle uitvoering van sy nywerheids- en handelsbeleid te fasiliteer. Ashton en Green (1996:160) onderskei tussen drie fases in die ontwikkeling van Singapoer se ekonomie.

- Gedurende die eerste fase is beleggings doelbewus deur buitelandse maatskappye gelok ten einde 'n sterk nywerheidsbasis, gebou op die beskikbaarheid van goedkoop arbeid, te vestig. Al wat die staat nodig gehad het om te doen op die gebied van onderwys was om 'n geletterde bevolking, wat in staat sou wees om basiese instruksies te volg, te ontwikkel. Gevolglik is basiese geletterdheid verskaf deur primêre onderwys, met slegs beperkte voorsiening vir sekondêre en hoër onderwys (Ashton \& Green, 1996:161-162; Beng, 1997:93).

- Die tweede fase van die ontwikkeling van Singapoer se ekonomie is gekenmerk deur die instelling van hoër waardetoevoegende produksie. Laagbesoldigde, arbeidsintensiewe nywerhede is vervang met kapitaalintensiewe, waardetoevoegende bedrywe (Ashton \& Green, 1996:162-163; Edwards, 1997:186; Porter, 1990:566). Ten einde die verskaffing van die benodigde menslike hulpbronne te verseker, het die regering die voorsiening van veral sekondêre, tegniese en beroepsgerigte onderwys uitgebrei. In 'n poging om die vaardighede van volwassene-werkers te verbeter is 'n reeks volwasseneonderwysprogramme geloods: die Basiese Onderwys vir Vaardigheidsopleidingsprogram, die Modulêre Vaardigheidsopleidingsprogram, die Werkverbetering deur Sekondêre Onderwysprogram, en die Kernvaardighede vir Effektiwiteit en Veranderingprogram (Beng, 1997:101). Dié programme word in modulêre vorm deur onderwys- en opleidingsinstitute en werkgewers verskaf.

- Die derde fase van die ontwikkeling van die Singapoerse ekonomie is gekenmerk deur die groei van kennisgebaseerde dienstenywerhede (Ashton \& Green, 1996:163-164). Ten einde te verseker dat alle skoolverlaters die basiese vaardighede wat nodig is vir die werkplek bemeester het, is besluit dat alle jongmense 'n minimum van tien jaar algemene en tegniese onderwys moet deurloop (Ashton \& Green, 1996:164).

Die integrasie van vaardigheidsbemeestering en nywerheids- en handelsbeleid vereis 'n hoë vlak van koördinering op regeringsvlak. Die staatsdepartement van Handel en Nywerheid het die taak om die land se toekomstige menslike hulpbronbehoeftes te identifiseer. Dié departement 
voeg dan die toekomstige menslike hulpbronaanvraag by projeksies oor die uitset van die onderwysstelsel. Die resultate word omgewerk tot teikens vir die Raad vir Professionele en Tegniese Onderwys (Ashton \& Green, 1996:170). Dié Raad vertolk die oorkoepelende teikens tot spesifieke teikens vir universiteite, politechnikons, skole en die Instituut vir Tegniese Onderwys.

\section{Sintese vanuit 'n Suid-Afrikaanse perspektief}

Die eerste gevolgtrekking wat uit bostaande oorsig na vore tree, is dat daar geen outomatiese of noodwendig kousale skakel tussen onderwysuitbreiding en ekonomiese groei/indiensneming skyn te bestaan nie. Schultz se menslike kapitaalteorie (vgl. Schultz, 1962) en Harbison en Meyrs (1964) se studie - laasgenoemde handel oor die moontlike korrelasie tussen lande se onderwysbelegging en hulle bruto binnelandse produk - het wel sodanige verband aangedui. Die teorie van menslike kapitaal het die teoretiese begronding verskaf vir 'n vertroue in onderwys en opleiding as wondermiddel om ekonomiese groei te verseker en werkloosheid uit te roei. Hierdie teorie was gevolglik 'n belangrike stimulus agter massale onderwysbeleggings en -uitbreidings in die ontwikkelende lande sedert die vroeë sestigerjare (vgl. Sobel, 1982). In die lande wat hierbo bespreek is, blyk dié vertroue op 'n oorvereenvoudiging, indien nie 'n wanopvatting nie, te berus. In al hierdie lande het onderwys- en opleidingsontwikkeling plaasgevind met die doel om 'n reeds bestaande en ontplooiende ekonomie te dien; ekonomiese groei het nie gevolg op onderwysuitbreiding soos die menslike kapitaalteorie, of die huidige ekonomies-politieke diskoers in Suid-Afrika (vgl. byvoorbeeld Department of Labour, 2001:5) dit wil hê nie. Ekonomiese ontwikkeling (wat afhanklik is van 'n gunstige ekonomies-politieke omgewing) moet eers volledig gevestig wees alvorens onderwys en opleiding ' $n$ rol kan speel in voortgesette ekonomiese groei en die uitskakeling van werkloosheid.

Die tweede gevolgtrekking wat uit die oorsig gemaak kan word is die volgende: om onderwys- en opleidingstelsels te voorsien wat die ekonomie kan voed en ondersteun, vereis veel meer as die voorsiening en die uitbreiding van 'n konvensionele, formele skolestelsel. Vir SuidAfrika, met 'n werkloosheidskoers van $25 \%$ tot $37 \%$, afhangende van watter definisie gebruik word (Department of Labour, 2001:5), en waarvan een van die doelstellings van die onderwysstelsel die verskaffing is van vaardighede aan leerders soos benodig deur die ekonomie (vgl. Steyn, 2000: 82), kan 'n kombinasie van die Engelse en Singapoerse modelle aanbeveel word. Die Britse New Deal-program skyn geskik te wees vir die vaardigheidsopleiding van werklose jeugdiges en volwassenes, terwyl Singapoer ' $n$ onderwysstelsel geskep het wat deurlopend in 
pas is met die veranderende aanvraag van die ekonomie. Die Departement van Arbeid van die Suid-Afrikaanse regering behoort van hierdie moontlikhede kennis te neem (vgl. Anon., 2001:2)

Die model van Duitsland (tweeledige stelsel) funksioneer goed in Duitsland, hoewel die vele pogings om dié model na ander lande te verplant feitlik oral klaaglik misluk (vgl. Stockmann, 1999; Wilson, 2000). Verskillende studies het die redes daarvoor teruggevoer na die verskille tussen die Duitse (kontinentale) konteks en dié van ander lande, by name dat die arbeidsbedeling in Duitsland sodanig is dat werkgewers self kan besluit of hulle leerders na voltooiing van hulle leerderskappe permanente aanstellings wil aanbied. Werkgewers neem dus graag deel aan die stelsel omdat dit vir hulle die kans bied om potensiële werkers onder werklike werksomstandighede waar te neem en sodoende ' $n$ lang, duur en riskante proses van werkerswerwing kan uitskakel (Campbell, 1993:66). Verder word salarisse vir alle beroepe in Duitsland nasionaal beding en vasgestel. Die stelsel verhoed individuele werkers om hulle verdienstes te verbeter deur van werkgewer te verander. Dit moedig ook werkgewers aan om leerders in te neem en in hulle opleiding te belê, aangesien dié stelsel werkgewers daarvan beskerm dat hulle konkurrente hulle werkers van hulle sal afrokkel (Hamilton, 1999:8). Die konteks kom nie ooreen met dié van Suid-Afrika nie. Die regering se vaardigheidsontwikkelingstrategie behels hoofsaaklik 'n program van leerderskappe volgens die Duitse model (vgl. Department of Labour, 2001; Mdlalana, 2002a; Mdlalana, 2002b). 'n Volledige moontlikheidsbepaling van so 'n stelsel wat al die kontekstuele ooreenkomste en verskille tussen Duitsland (feitlik die enigste land waar die stelsel 'n sukses is) en Suid-Afrika verreken, val buite die omvang en raamwerk van dié artikel, en sal 'n waardevolle opvolgstudie tot dié navorsing kan wees. Wat wel hier verklaar kan word, is dat uit die versameling buitelandse suksesmodelle wat in dié artikel bespreek is, dié van Singapoer en Brittanje eerder as navolgenswaardig vir Suid-Afrika voorgehou kan word.

Daar is gewys op die feit dat die model wat in die navorsing gebruik is, 'n oorvereenvoudiging van die werklikheid is, en dat die model byvoorbeeld die rol van die informele ekonomiese sektor negeer. 1.74 miljoen van die Suid-Afrikaanse bevolking is tans werksaam in die informele ekonomiese sektor. Van dié 1.74 miljoen bedryf 1.33 miljoen hulle eie ondernemings, terwyl 0.41 miljoen in diens van werkgewers in die informele sektor is (statistiek vanaf Statistics South Africa, 1999; vanuit 1996 sensus, ongepubliseer). Sover as wat vasgestel kan word, het 'n Wêreldbankstudie in die Ivoorkus die informele ekonomiese sektor op die onderwysnavorsingskaart geplaas. 
Dié studie het onder andere tot die volgende bevindinge gekom (vgl. World Bank, 1988:71): Privaatopbrengskoerse ("private rates of return") van universiteitsgegradueerdes wat in die informele sektor aktief is, is hoër as dié van universiteitsgegradueerdes wat in die formele sektor betrekkings bekom het. In Abidjan is die gemiddelde verdienste van 'n persoon in die informele sektor met 'n beroepsgerigte of tegniese diploma een en 'n half keer dié van 'n staatsdiensamptenaar met dieselfde kwalifikasie, en meer as drie maal dié van 'n eie-werkverskaffer met net 'n primêre skooleindsertifikaat. Die buitengewoon positiewe, ekonomiese wins van onderwyspeil in die informele ekonomiese sektor is 'n bevredigende teken vir die moontlikheid van plaaslike navorsing oor onderwysvoorsiening aan dié deel van die bevolking wat in die informele sektor werksaam is. Tot dusver was sodanige navorsing afwesig.

Ten slotte behoort dit vanuit 'n reformatories-opvoedkundige perspektief duidelik te wees dat die onderwys- en opleidingstelsel van 'n land slegs 'n ekonomiese bedeling behoort te ondersteun en te bevorder wat voldoen aan die beginsels van rentmeesterskap en verantwoordelike respons teenoor God en die medemens. Onderwys en opleiding behoort nie 'n ekonomiese en finansiële opset te ondersteun waarin die vryemarkstelsel (kapitalisme) opsigtelik besig is om homself te verteer (vgl. Malala, 2002:16) en waar die beginsels van rentmeesterskap en verantwoordelike respons blatant verontagsaam word nie. Ekonomiese en finansiële stelsels wat hierdie beginsels misken, kom tot 'n val, soos onlangs geblyk het in die ineenstorting van die economic bubbles van Suidoos-Asië en die Verre Ooste, die dot.com-bomb in die inligtingstegnologiebedryf in die VSA en die res van die Westerse wêreld, en die ernstige ouditeringskandale in korporatiewe Amerika, onder meer by prominente maatskappye soos Andersen, Tyco, Global Crossing, Qwest, WorldCom, Xerox, Vivendi, Merck Bristol-Myers Squibb, Elan, Halliburton, Harken Energy, Enron en verskeie ander (vgl. ook Bullard, 2002:4). Die val van piramideskemas en ander vorme van ekonomiese bedrog en wandade in Suid-Afrika en elders in die wêreld toon ook dat die ekonomies-finansiële stelsels van die global village waarin die hedendaagse mens leef, nie op die vermelde twee beginsels gegrond is nie. Onderwyskundiges behoort dringend op ekonomiese hervorming aan te dring alvorens hulle die ekonomie met oorgawe deur middel van onderwys- en opleidingsprogramme ondersteun.

\section{Slotopmerking}

Hoewel daar 'n noue skakeling tussen ekonomiese stelsels en die geassosieerde vorme van onderwys en opleiding bestaan, is die verband nie eenvoudig, kousaal-reglynig, nie. Die koppeling tussen die ekonomie en die onderwys is dus geen eenvoudige prosedure nie. Dit is duidelik 
dat gesofistikeerde ekonomieë deur verskillende fases van ontwikkeling gaan, en dat die onderwys met hierdie ontwikkelinge behoort tred te hou, of hulle behoort te ondersteun en bevorder. Vanuit 'n prinsipiële standpunt is dit egter eweneens duidelik dat ekonomieë neig om in duie te stort of te wanfunksioneer indien hulle nie voldoen aan die Bybelse beginsels van die mens as rentmeester of mandaathouer van God, en van verantwoordelike respons teenoor God en die mensdom ten opsigte van dit wat aan die mens toevertrou is nie. Die onderwys- en opleidingstelsel van 'n land behoort derhalwe nie 'n ekonomiese bedeling te ondersteun en te bevorder wat nie aan hierdie beginsels voldoen nie, maar behoort eerder daarteen te getuig en op hervorming aan te dring.

\section{Bibliografie}

ANON. 2001. The Labour Market Skills Development Programme. Sunday Times: 2, Dec. 30.

ASHTON, D, \& GREEN, F. 1996. Education, training and the global economy. Cheltenham : Elgar.

BADENHORST, O. 2000. All aboard the office trains. Finance Week: 7, Jan. 29.

BENG, C.H. 1997. Can governments engineer the transition from cheap labour to skill-based competitiveness? The case of Singapore. (In Godfrey, M., ed. Skill development for international competitiveness. Cheltenham : Elgar, p. 92-138.)

BHORAT, H. \& HODGE, J. 1999. Decomposing shifts in labour demand in South Africa. South African Journal of Economics, 67(3):348.

BLAUG, M. 1973. Education and the Employment Problem in Developing Countries. Geneva : International Labour Office.

BLOSSFELD, H.P. \& STOCKMANN, R. 1999. The German dual system in comparative perspective. International Journal of Sociology, 28(4):3-28.

BOOTH, A.L. \& SNOWER, D.J., eds. 1996. Acquiring skills: market failures, their symptoms and policy responses. Cambridge : Centre for Economic Policy Research.

BULLARD, D. 2002. Why auditors now rank with used car salesmen and lawyers. The Sunday Times: Jul. 14.

CANTOR, L. 1989. Vocational education and training in the developed world: a comparative study. London: Routledge.

CAMPBELL, C.B. 1993. The German dual-system of apprenticeship training for youth: a best practices study. Canadian and International Education, 22(2):51-67.

CAPPELLI, P., BASSI, L., KATZ, H., KNOKE, D., OSTERMAN, P. \& USEEM, M. 1997. Change at work. New York : Oxford University Press.

DEKKER, E. 1995. The education system of the Federal Republic of Germany. (In Dekker, E. \& Van Schalkwyk, O J., eds. Modern education systems. 2nd ed. Johannesburg : Heinemann. p. 47-132.)

DEPARTMENT OF LABOUR, 2001. Vhutsila. Our skills development strategy. Pretoria : Department of Labour.

DOUTHWAITE, R.J. 1996. Short circuit: strengthening local economies for security in an unstable world. Devon : Green Books.

DUGGAN, S.P. 1916. A student's textbook in the history of education. New York : Appleton-Century. 
EDWARDS, C. 1997. State failure or market failure? The ten steps to a levy-grant system of vocational training. (In Godfrey, M., ed. Skill development for international competitiveness. Cheltenham : Edward Elga. p. 169-200.)

FÄGERLIND, I. \& SAHA, L.J. 1989. Education and national development: A comparative perspective. 2nd ed. Oxford : Butterworth-Heinemann.

FOURIE, F.C. v.N. 1999. How to think and reason in macro economics. Kenwyn : Fourie \& Juta.

FULLER, T. 2001. 'Generation Slump' a concern for Japan. The Straits Times: April, 12.

GO, R. 2001. Jakarta luxury tax makes investors rethink options. The Straits Times: April, 12.

GOODEY, J.S. 1989. Die onderwysstelsel van Engeland. (In Dekker, E. \& Van Schalkwyk, O.J., reds. Moderne onderwysstelsels. Durban : Butterworths. p. 121162.)

GOODEY, J.S. 1996. The education system of England. (In Dekker, E. \& Van Schalkwyk, O.J., eds. Modern education systems. 2nd ed. Johannesburg : Heinemann. p. 171-220.)

GRIFFITHS, H.R. \& JONES, R.A. 1980. South African labour economics. Johannesburg : McGraw-Hill.

HAMILTON, S.F. 1999. Germany and the United States in Comparative Perspective. International Journal of Sociology, 29(1):3-20.

HARBISON, F.H. \& MEYRS, C.O. 1964. Education, Manpower and Economic Growth: Strategies for Human Resource Development. New York : Macmillan.

HOARE, S. \& JOLLY, A., eds. 1999. Skills and training handbook. London : Kogan Page.

HUSÉN, T. 1979. The school in question. A comparative study of the school and its future in Western society. Oxford : Oxford University Press.

INTERNATIONAL LABOUR OFFICE. 2000. Yearbook of Labour Statistics. Geneva : International Labour Office.

KENNEDY, P. 1993. Preparing for the twenty-first century. London : Fontana Press.

KÖNIG, A. 2001. Fokus op die 300 geloofsvrae wat mense die meeste vra. Wellington : Lux Verbi.

KUIPER, M. 1995. Voorwoord. (In Taljaard, J.A.L. 1995. Die sewende dag. Piet Retief : Veritas Pers. p. v-viii.)

LEWIS, L. 1999. Britain's New Deal: delivery through partnerships. (In Hoare, S. \& Jolly, A., eds. skills and training handbook. London : Kogan Page. p. 34-38.)

MALALA, J. 2002. Marx was right; capitalism is eating itself. The Sunday Times: Jul. 14.

McCREADY, P. 2001. Fear and unity in the streets of Genoa. The Sunday Times: Jul. 29.

MDLALANA, M.M.S. 2002a. National skills develoment strategy. The Citizen: March, 26.

MDLALANA, M.M.S. 2002b. National skills development strategy: Why South Africa does need it. The Citizen: Jul. 14.

MIDDLETON J.R. \& WALSH, B.J. 1995. Truth is stranger than it used to be. Downers Grove : InterVarsity Press.

MURNANE, R.J. \& LEVY, F. 1996. Teaching the new basic skills: principles for educating children to thrive in a changing economy. New York : Free Press.

MURRAY, M. 1999. A skills and training strategy for Britain. (In Hoare, S. \& Jolly, A., eds. Skills and training handbook. London : Kogan Page. p. 4-9.) 
NEEF, D. 1999. A little knowledge is a dangerous thing: understanding our global knowledge economy. 2nd ed. Boston/Butterworth : Heinemann.

OLIVIER, A. \& DUVENHAGE, H. 2001. Nou wag eksamen in oorlewing. Rapport: 2, Des. 30.

PORTER, M.E. 1990. The competitive advantage of nations. New York : Free Press.

POWELL, A. 1999. The new network National Training Organisations - leading the drive for world class skills. (In Hoare, S. \& Jolly, A., eds. Skills and training handbook. London : Kogan Page. p. 43-49.)

PRAIS, S.J. 1995. Productivity, education and training: an international perspective. Cambridge : Cambridge University Press.

PRETORIUS, S.G. 1995. The education system of Japan. (In Dekker, E. \& Van Schalkwyk, O.J., eds. Modern education systems. 2nd ed. Johannesburg : Heinemann. p. 317-365.)

SCHULTZ, T.W. 1962. Investment in human capital. American Economic Review, L1(2):1-20.

SCHUURMAN, E. 1987. The future: Our choice or God's gift. New Zealand : Exile Publications.

SCHUURMAN, E. 1995. Perspectives on technology and culture. Potchefstroom : IRS.

SOBEL, I. 1982. The human capital revolution in economic development. (In Altbach, P.G., Arnove, R.F. \& Kelly, G.P., eds. Comparative Education. New York : Macmillan. p. 54-77.)

STATISTICS SOUTH AFRICA. 1999. Statistieke aan skrywer verskaf.

STEYN, S.C. 2000. The education system of South Africa. (In Steyn, H.J. \& Wolhuter, C.C., eds. Education systems of emerging countries: Challenges of the 21st Century. Potchefstroom : Keurkopie. p. 53-140.)

STIGLITZ, J.E. 1996. Some lessons from the East Asian miracle. World Bank Observer, 11(2):151-177.

STOCKMANN, R. 1999. The implementation of a dual vocational training in developing countries: An evaluation of "dual projects" assisted by the German agency for technical cooperation. International Journal of Sociology, 29(2):29-65.

TALJAARD, J.A.L. 1995. Die sewende dag. Piet Retief : Veritas Pers.

THERON, A.M.C. \& VAN STADEN, J.G. 1989. Die onderwysstelsel van die VSA. (In Dekker, E. \& Van Schalkwyk, O.J., reds. Moderne onderwysstelsels. Durban : Butterworths. p. 397-441.)

VAN DYK, P.S., NEL, P.S., LOEDOFF, P. van Z., HAASBROEK, G.D. 1997. Training management: a multidisciplinary approach to human resources developments in South Africa. Johannesburg : International Thomson Publishing.

WELLS, A. 1999. Better basic skills, better work. (In Hoare, S. \& Jolly, A., eds. Skills and training handbook. London : Kogan Page. p. 23-27.)

WILSON, D. 2000. The German "Dual System" of occupational training: a muchreplicated but oft-failed transfer. (Paper presented at the March 2002 annual conference of the Comparative and International Education (CIES) Society, March 2000, San Antonio, Texas, USA.)

WOLHUTER, C.C. 1993. Gelyke onderwysvoorsiening in die RSA met besondere verwysings na die implikasies daarvan vir onderwysvoorsiening in die RSA. US : Universiteit van Stellenbosh. (D.Ed.-proefskrif.)

WORLD BANK. 1988. Education in Sub-Saharan Africa: Policies for adjustment, revitalization and expansion. Washington DC : World Bank.

WORLD BANK. 1993. The East Asian miracle: Economic growth and public policy. Washington DC : World Bank. 


\section{Kernbegrippe:}

ekonomiese ontwikkeling onderwys

opleiding

rentmeesterskap

verantwoordelike bestuur

\section{Key concepts:}

economic development

education

responsible management

stewardship

training 